\title{
THE THEOLOGICAL INTERPRETATION OF THE BOOK OF EXODUS AS NARRATIVES CONCERNING ORIGIN AND MIGRATION AS AN ONGOING NEGOTIATION OF IDENTITY BY THE TIV PEOPLE OF NIGERIA
}

\author{
Jonathan Weor \\ Old and New Testament \\ Stellenbosch University
}

\begin{abstract}
In his search for the components or aspects of dialogue with the Bible particularly in Africa, West (2008:48) mentions five comparative approaches of Ukpong (2000:17-18). Using the third approach, which deals with the interpretation of biblical texts against the background of African cultures, religions and life experiences aimed at new understanding of the biblical text that would be informed by the African context and circumstance, this article argues that the Tiv people of Nigeria read and interpret Exodus as an ongoing identity negotiation and not merely as a historical, literary, liberating, postcolonial and feminist text as it has been read and interpreted over centuries by different exegetes. The article describes the narratives of origin and migration of the Tiv and establishes their relevance and/or impact on the theological apparition and interpretation of Exodus traditions amongst the Tiv as an ongoing progression of identity formation.
\end{abstract}

Key Words: Book of Exodus, Theology, Origin, Migration, Tiv

\section{Introduction}

There are narratives concerning origin, which are constituted of various cultures as found in the Old Testament particularly in Exodus. The Tiv people of Nigeria in a similar way have fascinating stories of origin and migration that are orally documented and passed from one generation to the other by word of mouth. These stories and the early experiences of the Tiv people reveal their previous knowledge of God and his dealings with humanity. The history and experiences of the Tiv people also serve as a building block in understanding the past, present, and future. This article sets out to describe the narratives concerning origin and migration of the Tiv people giving relevant examples based on recent empirical research conducted amongst selected clans of the Tiv (Ityuluv-ya, Turan, Ipav, Masev) in 2008/2009. The article will also discuss the relevance of the Tiv narratives of origin and migration in the theological appropriation and interpretation of the Exodus tradition amongst the Tiv people of Nigeria.

\section{A Description of the Tiv Origin and Migration Narratives: Read as an Ongoing Process of Identity Negotiation}

According to Gbor (1978:1) and Yakobu (s.a. 4) the origin of the Tiv can rightly be traced in two forms. On the one hand it can be traced from the ancestry origin in terms of blood 
relation and on the other hand it can be traced from the geographical point of view, which deals with the place/location of ancestors of the Tiv before migrating to the Benue province where they are now. In both versions according to the author there are different versions legendary held by both writers on Tiv and/or Tiv respondents themselves, thus the whole issue becomes polemical.

During my structured interviews with the individual and focus group members of two clans in Kwande local government, namely Ityuluv and Turan, one of the questions asked was: who are the Tiv people? And where do the Tiv people come from? The two abovementioned clans said the Tiv are children of Takuruku and that Congo in Zaire is the place where the Tiv ancestry parents first lived and migrated from among other Bantu tribes. The clans also held that the Tiv settled long at Swem in Cameroon, the country neighbouring the Tiv people until now, especially those living across the border in Nigeria. The clans also add that Tiv people did not all migrate to Benue and that some such as the Utanga, Iyon, Ityuluv-ya and Nyiev-ya are still living near the Swem Mountain in the present Cameroon (Weor 2011:69-70).

The abovementioned clans also acknowledge the fact that the Tiv were led by Karagbe, a God fearing and humble man from Masev clan. Karagbe they said was given divine powers in the form of a pot from the unseen spirits called 'adzov' on the mountain of Swem. The contents of the pot they said include 'ayande'-weeds, ashes believed to be the remains of Takuruku, the late ancestor of the Tiv and a stone believed to have been dropped from the sky through thunder and lightning. The pot according to the Tiv belief contains laws and divine power that aided Karagbe and the entire Tiv people to journey in obedience and confidence to arrive in the Benue province where they are now. The Swem pot amazingly is used in law courts in Nigeria for oaths taking among the Tiv (Weor 2005:890).

The selected clans also claimed that the Tiv had knowledge of the Zulu people living in South Africa and that they taught them how to fight with arrows during their encounter with them following their migration episode from Swem. These memories about the Zulu are embedded in stories, as well as warlike songs about 'Shaka, the eminent king of the Zulu kingdom'. How the Tiv are linked to the Zulu in terms of origin of both place and blood lineage, no one could venture an opinion with any certainty - respondents said those who knew about the Zulu passed away long ago with no written record left behind.

The clans also shared their migration experiences such as fighting wars on the way to gain entrance in the course of penetrating other people's land. When asked how they have managed to settled in Benue province as their permanent abode, both clans maintain that the Tiv fought and triumphed over the original inhabitants of Benue using their poisoned arrows before they finally settled there. The clans also claimed that the fertile land of the Benue valley was meant for them by God in the sky for farming activities and that their victory was from the sky God as well. Thus the Tiv claim that fighting and displacing the original citizens of Benue and taking over their land as permanent occupants was not an act of wickedness but rather a fulfilment of God's plan for them (Weor 2011:67-71).

When asked when the event of migration and settlement of the Tiv in Benue province (Nigeria) took place both clans were unable to settle on any certainty since the events were orally documented and transmitted differently based on collective memories. The selected clans however, seem to agree on a time of origin somewhere during the $16^{\text {th }}$ century $(1540)$ as was mentioned by several respondents. The uncertainty of the exact date can be argued in terms of the prevailing oral traditions on the Tiv narrative of origin and migration 
resulting in different views as gathered and transmitted over time by people of different memories and collective abilities.

One can ascertain from the abovestated answers gathered from the selected clans of the Tiv that they are knowledgeable of their origin (ancestry and place) and migration narratives. The Tiv as gathered from the empirical research done with selected tribes amongst them also shows that there are ongoing identity negotiations within their tribe, which is traced from the two lineage sons of the Tiv namely, 'Ichongo' = circumcised and 'Ipusu' $=$ uncircumcised respectively. On a general note however, one can establish that the Tiv people are children of one ancestral father - Takuru, an African from the Congo.

On the issue of migration of the Tiv too, one can argue that it is traceable though surrronded by different accounts ranging from Congo (Zaire)-Swem (Cameroon metropole) to Zululand (South Africa) to the southern part of Nigeria (among the Ekoi of Cross River State) - the northern part of Jos (Plateu State) and finally down to the Benue plains of central Nigeria where they are now (Bohannan 1933:12-17; Downess 1953:viii). ${ }^{1}$ The different accounts are argued as proof for the oral nature of the Tiv narratives of origin and migration which is polemical in nature but acceptable by the Tiv tribe and passed on to subsequent generations by word of mouth despite the exsistence of little written Tiv literature at present (Bosman 2005:869-877).

\section{The Impact of the Narratives Concerning Origin and Migration of the Tiv on the Theological Appropriation and/or Interpretation of Exodus among the Tiv of Nigeria}

Emphasis on the abovementioned subheading will be on how Exodus plays a part in the identity formation of the Tiv of Nigeria and in what way the narrative of origin and migration influence the way they read, understand and interpret Exodus using their oral context full of stories of real life circumstances and experiences. In other words, how do the Tiv people rethink the Exodus or its interpretation in their own context to generate new interpretation/meanings by way of analogy?

To go about the abovementioned task a focus group was conducted with eight participants each from two selected clans (Masev and Ipav of Gwer and Gboko Local government areas) $)^{2}$ to partake in the group discussion. These focus group discussions lasted approximately an hour during which it was recorded on tapes and notes taken on paper,

\footnotetext{
The Tiv live south of the Benue River in gently rolling country. They are attractive, stout hearted (brave, determined, and strong) people, hard-working and in earlier days brave warriors. They had resisted the invasions of the Muslims, the Hausa, and the Fulani who pressed down from the North, and were little affected by the Ibos and other Nigerian tribes in the South. They were one of the last tribes in Nigeria to be brought under the rule of law imposed by the Colonial government. It was only in the late 1920s and early 1930s that government began to gain knowledge of them (Downes 1971:vii).

2 Masev $=$ Gwer Local government is a clan where Karagbe the leader of the Tiv hails from and 'Ipav'= Gboko Local government which served as the seat of government of the Tiv people during the time of the British administration until now. 'Ipav' clan also served as the first Mission station during and after the missionary advent in Tiv. While selecting participants randomly from these clans for group discussions it was fascinating to see how their identity influence their understanding and interpretation of Exodus (my personal experience as a Tiv researcher - born, reared, studied, lived and worked amongst the Tiv).
} 
to be transcribed and interpreted at a later stage (Weor 2011:78-81, Unpublished PhD Thesis). ${ }^{3}$

Three texts were selected from Exodus to be read and interpreted by the respondents according to their own tradition and understanding. The researcher first reminded the respondents of the Tiv narratives concerning origin and migration and then read the texts (Ex. 14:21-29 =crossing the Red Sea; 19:10-20 =Wilderness wandering and 20:1-17 = the Ten Commandments), using the Tiv version of the Bible (Bibilo $i$ ken zwa Tiv). After the reading the researcher asked the respondents probing questions to establish how they had interpreted these texts in their own way and context.

- Exodus 14:21-29: This passage describes how the Israelites crossed the Red Sea on dry ground and how the Egyptians perished due to the intervention of God in favour of his chosen nation

The researcher asked his respondents whether they had found any similarities between the Exodus narratives and the migration experience and/or story of the Tiv people. Many respondents, especially the elderly ones, laughed and said that the story of the Tiv people is exactly the same as the story that was read from the Bible. The Tiv people migrated from Congo to Benue just as the Israelites from Egypt to Canaan. The Tiv people had Karagbe from Masev who was a humble and God fearing man as their leader just like Moses was a leader of the people of Israel. The Tiv also crossed the Mkoomon River on the back of a green snake that stretched itself like the stick of Moses to enable Tiv people to cross over to the other side. The enemies of the Tiv like the Chamber, Ugenyi, Ukwese, and Ndir who were pursuing them from behind, also followed on the same back of the snake but the snake withdrew itself and let all fall into the river where they drowned. They claimed that the green snake acted in the place of God to save the Tiv people. They also said that the story in Exodus is their story - the authors of the Bible only replaced their name with Israel (Weor, JT 2011: PhD Thesis - Unpublished).

The researcher also asked his respondents to tell him what Exodus 14:21-29 communicates about God. They all said in a chorus that God loves his people and he hates those who seek to maltreat others due to the power they had. Some added that God does side with the oppressed against the oppressors. God supported the Israelites in the Bible and supported the Tiv people throughout their migration episode until they secured Benue in which to settle.

- Exodus 19:10-20: The Lord asked Moses to consecrate the Israelites before they would meet him on Mount Sinai for the giving of the commandments. Only Moses was permitted to go to the top of the Mountain to meet God

The respondents were asked about the reasons behind the ritual of cleansing which the Israelites were asked to perform before meeting God on Mount Sinai. The first respondent who was a traditionalist and among the older men in the group said God wanted to initiate people into his holiness before they would meet him. He further commented that it seemed quite similar to what the Tiv practitioners of akombo rituals do. When an uninitiated person comes near an akombo festival or shrine, he/she has to remove their shoes to avoid defiling

A similar focus group discussion was held with the Ityuluv and Turan clans of Kwande Local Government where similar responses found in the second focus group with Masev and Ipav of Gwer and Gboko Local government were noted - all of Benue State was heard. Owing to limited time and space only the responses generated from the second focus group with Masev and Ipav will be discussed in this article. 
the akombo place that was considered as holy ground by the practitioners. Similarly uninitiated persons were not allowed to eat of akombo ritual meals without being initiated into it. Menstruating women, men who had sexual intercourse previously, people who touch dead bodies and those with contagious diseases such as leprosy, gonorrhoea, open wounds, chicken pox and so forth were not allowed to an akombo shrine or festival since they were unclean to do so unless a cleansing ritual was performed to make them clean. These they said were similar to the cleansing that God ordered the Israelites to do before meeting with him on Mount Sinai.

Other respondents simply said God is holy thus He wants his people to approach him with clean hearts before He would accept them. An older male respondent commented that God is clean and hates anything dirty such as adultery, murder, stealing, disrespect, disobedience and hatred. He looked up in the sky and said to prove that God likes cleanliness where he is dwelling is also colourful and that he does not want his feet to touch the ground like ordinary people that is why he is staying high in the sky above human beings.

The researcher reminded his respondents that the Israelites according to the text were given the commandments on Mount Sinai after they had crossed the river Jordan. He then asked them to tell him the relevance of such commandments to the Israelites. The respondents' contributions on this matter show that rules are a guide to people since human beings have different thoughts and minds that act differently. They also said if there are no laws there will be no order and no order implies that no one would fear God. Some further said that God wanted to tell the Israelites what he likes and dislikes and what will happen to them if they obey and/or disobey him - blessings for obedience and curses for disobedience just like parents and children in homes where obedient children are hardly beaten but disobedient children are subject to hard discipline. Some of the respondents added that even among the Tiv people every home has rules guiding its members and visitors for the sake of discipline and safety.

\section{- Exodus 20:1-17: The Ten Commandments}

The respondents said Tiv people have not gotten laws which are written down formally as it is the case with law courts and the Bible. However, there are laws that are formulated by each head of a family and which are meant for maintenance of order ( e.g. laws concerning marriage and sexuality, good neighbourliness, worship of gods and idols, respect for elders and unseen spirits, sacrificial acts/cult practices, festivals, divination, honesty, peace and taboos ). It follows subsequently up to the Tiv main court of appeal called ijir tamen and chaired by the overall chief of the Tiv people - Tor-Tiv in the present day Tiv. In the olden days they said the voice of elders were taken serious more than lay down laws and people were more obedient to elders than now; thus Tiv were guided by prescribed laws of elders at the nuclear family, extended family, and clan (Weor 2005:886).

The researcher asked his respondents which commandment they considered most relevant to the Tiv tradition. Female respondents first mentioned adultery since virginity is held with pride among Tiv mothers. The men at this point supported their wives saying adultery can bring hatred and remove love - the greatest of the rest of the commandments. Amongst the Tiv you are not allowed to go to the battlefield for your enemy will kill you in revenge if you have committed adultery. Also when you are found guilty of adultery and you are shot by your enemies in a battlefield no one will remove the poisonous spear or arrow from you, thus you will die. Elderly respondents in the group emphasise the commandment that deals with respect for one's father and mother since respect for elders is practiced amongst the Tiv. The Tiv people believe that children and youngsters who 
disrespect elderly people are subject to die young as a curse while those respecting their parents and elderly people will live longer to be respected by younger generations as well.

Other commandments considered important were that of murder and bearing of false witness against a neighbour. The Tiv people believe that any death has a cause, thus when you kill someone the elders would curse you saying the blood of the deceased should go with you from generation to generation. Other respondents said Tiv people hate a lie and that is why they have a Swem divination pot for oath taking: when you tell a lie after sworn by the Swem divination pot then your legs and abdomen will become swollen and you will subsequently die (Weor 2011:69-76).

Viewed from the analysis of the qualitative research conducted amongst the Tiv of Nigeria one will argue that the Tiv readers of Exodus still hold to their culture and context that reveals their past history of origin and migration. And that for the Tiv readers of Nigeria to understand and interact with the written text of Exodus to come out with a new interpretation and/or meaning, their socio-cultural context has to be placed in the centre of Biblical interpretation by way of enculturation (Ukpong 1999:18). This is necessary because culture plays an important role in the understanding of the Bible, particularly among the Tiv people who are from an oral background. To disassociate ordinary Tiv readers of the Bible from their cultural background, which functions as a text to them and is mirrored in any biblical interpretation, makes the understanding much more complex for them.

As Masenya (1999:238) once said 'one's reading is shaped by his or her experience and that, the experience of the reader will always play a role in a reader's encounter with the Bible.' This is true of the Tiv reader of the Bible who considers their own past experience as their first text and significant for the interpretation of the Bible, particularly Exodus. The relevance and significance of the Bible can be comprehended in relation to the past experiences of Tiv readers and the apparent similarities of their origin narratives with that of the Biblical Exodus. Relating the Bible to the Tiv people in terms of their past social, cultural, religious and historical experiences will enable them to interact with the literary text of Exodus by way of appreciation of inter-textual allusions used in the interpretation of the Bible. In this way the Tiv readers will find Biblical events similar to their own past experiences and this will enable a more adequate understanding and interpretation of Exodus based on their context (Weor 2005:888).

\section{Conclusion}

This article has basically analysed the results obtained from the empirical research - both structured and focus groups - done amongst the Tiv of Nigeria in 2008/2009. From the analysis of the results this article observed that similar responses were derived from participants representing both clans (Ityuluv, Turan, Masev and Ipav). The clans, for example, both traced their origin from Congo through Swem in Cameroon to Benue in Nigeria in terms of place origin. The clans both indicated that Takuruku is their ancestral father as far as lineage origin is concern. Both clans acknowledged the fact that Karagbe of Masev was a leader of the Tiv in their migration period just as Moses in the Exodus tradition was the leader of Israel during their migration episode. According to the clans the Israelites crossed the Red Sea on dry ground with their enemies - the Egyptians and their chariots all drawn - as was the case with the Tiv who also crossed river Mkoomon on the back of a green snake (ikyarem) with their enemies (ugenyi, Ndir, Chamber, Ukwesi) also drawn in an attempt to cross over to attack them. 
The Israelites were given the Ten Commandments as a guide on Mount Sinai through Moses similar to the Swem pot that was given to the Tiv by adzov on the Mountain of Swem through Karagbe their leader. The Swem pot functioned as a law book and guide to the Tiv then - and now - similar to the Ten Commandments and the people of Israel and/or the believing community. Only Moses was allowed to meet with God on Mount Sinai to collect the tablet of the Ten Commandments; similarly Karagbe, the leader of the Tiv, was the only one that met the sprite or shape changers (adzov) on the Mountain of Swem to collect the Swem pot. The clans also pointed out that God is holy and expects his people to approach him in holiness; that is why the people of Israel had to sanctify themselves before meeting with him on Mount Sinai. The Tiv people also did a similar thing to their idols, which represent God on earth. Before entering into an idol house (or shrine) one has to remove one's shoes in most cases to maintain holiness. Men with open wounds, chicken pox, measles, leprosy, gonorrhoea, those who had touched dead bodies and had had sexual intercourse previously, were also not allowed to enter into an idol house (or shrine) except when a cleansing ritual was done to make cleanse them. Menstruating women were also not allowed to visit idol shrines and/or go near their husbands while preparing to take up arms in a war. This shows that the Tiv people also believed in the idea of the holiness of God albeit in their own exceptional ways similar to the Biblical Israelites in Exodus.

The abovementioned clans also pointed out that Tiv people consider so importantly the fifth, sixth, seventh, eight, and ninth commandments found in Exodus 20:1-17 $7^{4}$ however, they do not neglect the rest. The Tiv people, as indicated by the two clans, do not have central laws guiding them formally like the Ten commandments for the Exodus people, though Swem pot is applied in law courts to ascertain truths amongst the Tiv people.

Looking at the above one would conclude that the two clans, though situated in different geographical regions and belonging to different lineage families of the Tiv, yet understood the Exodus texts read to them and interpreted it in their own context using their past experiences. That then helps the researcher to ascertain his hypothesis and aim of his studies namely that the narrative concerning origin and migration of the Tiv of Nigeria can be used as the indigenous interpretive means for the theological appropriation of the Exodus tradition amongst them (MC Knight 1998:4-5; Weor 2005:886).

That is to say approaching the Tiv people with any Biblical text must do justice to their oral context and culture that is filled with stories of origin and migration and coupled with other circumstances in life such as poverty, political/economic crises, religious crises, HIV/AIDS, land crises, famine, war, etc. (Ukpong 1999:18; Masenya 1999:238). This will help the Tiv readers and interpreters of the Bible to place their personal life experiences on the one side and the Biblical text on the other side, and by way of analogy draw some parallels from the two texts to aid them generate a new interpretation that is based on their context (MC Knight 1998:4-5; Masenya 1999:238; Weor 2005:886). That is part of the oral context of the Tiv people and can only make meaning through verbal testimonies as it interacts with the literary text of Exodus to produce new meanings and/or interpretations that are contextualized (Vansina 1965:19).

The fifth commandment says: 'Honour your father and mother that your days may be long'. The Tiv believe that people who do not respect elders will die young. The sixth commandment prohibits murder. The Tiv people hate shedding blood of innocent people but encourage good neighbourliness instead. The seventh commandment on the one hand prohibits adultery which is held to high esteem amongst the Tiv people. The eighth commandment prohibits theft as the ninth commandment prohibits lying. All are essential commandments thoroughly observed by the Tiv people and not forgetting the rest of the commandments too (My personal experience as a born Tiv man living and working amongst them). 


\section{BIBLIOGRAPHY}

Bohannan, P \& Bohannan, L 1953. The Tiv of Central Nigeria. London: International African Institute.

Bohannan, P 1957. Justice and Judgement among the Tiv. London: Oxford Intervarsity Press.

Bosman, HL 2005. "Origin and identity: rereading Exodus as a polemical narrative then (Palestine) and now (Africa).” Scriptura: 90:869-877.

Downes RM 1933. The Tiv Tribe. Kaduna: Government Printer.

Downes, RM 1971. Tiv Religion. Ibadan: University Press.

Gbor, J 1981. Mdugh u Tiv man Mnyer ve hen Benue. Zaria: Gaskiya Corporation Ltd.

Masenya, MJ 1999. “Biblical Authority and the Authority of Women's Experiences: Whither Way?" Scriptura 70:229-240.

McKnight, EV 1985. The Bible and the Reader: An Introduction to Literary Criticism. Philadelphia: Fortress.

Ukpong, JS 1999a. "Models and Methods of Biblical Interpretation in Africa". Neue Zeitschrift Missionwissenschaft 55:4.

Ukpong, JS 1999b. "Can African Old Testament Scholarship escape the historical critical approach". Newsletter on African Old Testament Scholarship 7:2-5.

Ukpong, JS 2000. "Developments in Biblical interpretation in Africa: Historical and Hermeneutical Directions". West, GO and Dube, M (eds.), The Bible in Africa: Transactions, Trajectories and Trends. Leiden: Boston-Brill.

Vansina, J 1965.Oral Tradition. London: Routledge and Kegan Paul.

Weor, JT 2005. "The Narratives of Origin and Migration of the Tiv people (of Nigeria) as an Indigenous Interpretive Resource for the Interpretation of the book of Exodus." Scriptura 90:885-891.

Weor, JT 2011. Interpreting the Passover in the Exodus Tradition among the Tiv as Narrative concerning Origin and Migration of the Tiv. PhD Dissertation submitted to Stellenbosch University.

West, GO 2008. "Interrogating the Comparative Paradigm in African Biblical Scholarship." West, GO and De Wit, H (eds.), African and European Readers of the Bible in Dialogue. Leiden Brill:37-64. 